\title{
THE EFFECT OF PERCEIVED RISK, CONSUMER LIFESTYLE AND ONLINE TRUST ON THE PURCHASE INTENTION OF FASHION PRODUCTS IN INSTAGRAM SOCIAL MEDIA
}

\author{
Taranggana Ari Sakti, Sukaris, Asep Saepuloh \\ Dept of Management, Faculty of Economics and Business, Universitas Muhammadiyah \\ Gresik \\ Author Correspondence: \\ Sukaris \\ sukaris21@umg.ac.id
}

\begin{abstract}
ABSTRAK
Penelitian ini bertujuan untuk menganalisis pengaruh perceive risk, consumer lifestyle dan online trust terhadap minat beli produk fashion pada media sosial Instagram di Surabaya. Adapun sampel dalam penelitian ini terdiri dari 75 responden. Variabel independen dalam penelitian ini adalah perceive risk, consumer lifestyle dan online trust, sedangkan variabel dependennya adalah minat beli Produk Fashion di Instagram. Teknik analisis data yang digunakan adalah regresi linier berganda dengan bantuan program SPSS. Hasil penelitian menunjukkan bahwa variabel perceive risk, consumer lifestyle dan online trust berpengaruh secara parsial terhadap minat beli produk fashion pada media sosial Instagram di Surabaya.
\end{abstract}

Kata Kunci: perceive risk, consumer lifestyle, online trust, minat beli

\begin{abstract}
This study aims to analyze the effect of perceived risk, consumer lifestyle and online trust on the purchase intention of fashion products on Instagram social media in Surabaya. The sample in this study consisted of 75 respondents. The independent variable in this study is perceived risk, consumer lifestyle and online trust, while the dependent variable is the purchase intention of fashion products on Instagram. The data analysis technique used is multiple linear regression with the help of the SPSS program. The results showed that the variable perceived risk, consumer lifestyle and online trust partially influenced the interest in buying fashion products on Instagram social media in Surabaya.
\end{abstract}

Keywords: perceived risk, consumer lifestyle, online trust, purchase intention

\section{INTRODUCTION}

Today's business activities are experiencing rapid development with the help of technology, there is a growing dependence on one another between the company's ability to use technology and the ability to implement a competitive strategy in achieving its goals. companies in the future according to Laudon (2015: 12). The number of technological developments that have sprung up, such as applications nowadays, are becoming various social media applications where the results of technology output can create opportunities for people to do business (kompas.com, 2018). In the last decade, the development of information technology has undergone substantive changes in shaping consumer behavior. With the internet, opportunities for consumers to make purchases become wider through various access to products / services and increase the ease of making purchases as stated by Sukaris et al., (2019) that technological advances through various media platforms, both print, electronic, digital media and social media contributes to the shift in consumer consumption patterns.

Social Media seems to be a necessity for the community as a means of carrying out various activities ranging from entertainment, 
doing business and has an important role in sharing information that has changed consumer behavior or other activities (SWA, 2016). In the economic field, all forms of sales, purchasing, distribution, and marketing transactions are known as Electronic Commerce. Today's consumers have taken advantage of the use of social media as a medium for shopping or what is called ECommerce (Kompas.com, 2017). The Ecommerce market in Indonesia has considerable potential to market products (DBS Research, 2017). This is supported by the results of a survey conducted by the Indonesian Internet Service Providers Association (APJII) in 2017 that internet users in Indonesia currently reach 143.26 million people or equivalent to 54.7 percent of Indonesia's total population of 262 million people. Internet users currently prefer to access social media to make online shopping transactions (detik.com, 2017). For Indonesians, shopping online through social media is an option that can save money and time, provide flexibility, and get a lot of information when making a decision without feeling compelled to buy (Eva Martha Rahayu, SWA 2014).

Kotler and Kevin Keller (2012: 568), social media is a communication activity that uses electronic media with the aim of attracting consumers or companies in various forms of writing, images, and information videos so that marketers can build increased communication with consumers. APJII survey results in 2016 show that Indonesian consumers prefer shopping through social media such as Facebook and Instagram rather than websites. This shows that consumer activity tends to use social media applications rather than accessing them through websites. Some of the social media that have been created have been felt by consumers to shop and find product information related to the goods to be purchased. The most popular social media are Facebook and Instagram. The largest number of social media users in the world come from Indonesia, who are Instagram users.

The rapid development of digital media has had a major impact on media change. Ultimately it has led to changes in views, concepts, and orientation, in other fields including communication fields such as eWOM, e-business and e-marketing. From a marketing perspective, new perspectives and modern market concepts oriented to the market or consumers, it is the electronic market. Meanwhile, in a business perspective, it creates new views and concepts called digital marketing. Now the interaction model has developed towards electronic interaction or modern e-commerce. One form of business and marketing activities that apply the concepts of electronic markets, digital marketing, and e-commerce which are currently prevalent is the online store business (Hartini et al., 2020), a

Survey conducted by a market research institute from New York that states Indonesia included in the 5 largest Instagram user countries in the world, ranking second after Sweden and beating Norway and Australia. Analytical research company Nielsen Holdings conducted a survey of more than 17,000 people in 11 cities in Indonesia (Jakarta, Bandung, Yogyakarta, Semarang, Surakarta, Surabaya, Denpasar, Medan, Palembang, Makassar and Banjarmasin). The information in it includes data on media usage to product use, which shows that along with the increase in smartphone users, online shopping is also followed. Strengthened by Google Indonesia, which conducts the latest research in the local e-Commerce industry on the number of online shopping activities in major cities of Indonesia. With the result that the capital city of Jakarta is not the city with the highest percentage of online shopping. In fact, Jakarta was once dubbed the capital of eCommerce in the country, but the number one position with the largest number of online shopping activities is the city of Surabaya. (Detik.com, 2017).

In this case, google trends presents data that the city of Surabaya is in the third position in East Java related to the interest in visiting shopping via Instagram. It has been proven from a survey conducted by Techinasia that the e-commerce market share is only $20 \%$ of the total online shopping market. In fact, social commerce as a more traditional method where the transaction process is carried out on social media platforms such as Facebook, Instagram, LINE and WhatsApp, dominates $80 \%$ of the market share with 2.7 million transactions per 
day. The culture of Indonesian society that prefers direct interaction as a method of transaction, such as the survey evidence above, is indicated as the main driver of massive buying and selling activities and the circulation of transaction value on social media.

According to Mario Gaw, chairman of the Indonesian FinTech Association, social commerce has great potential in opening up access to more than 50 million small and medium enterprises (SMEs), which are estimated to absorb $96 \%$ of workers in Indonesia to distribute their products and services. The activities of SMEs themselves are predicted to contribute $58 \%$ to Indonesia's gross domestic product (GDP) and be an important contributor to national economic growth. The position of social commerce is irreplaceable. The public in general still prefers to shop through social media rather than from websites, and this makes it easier for industry players to educate consumers about online shopping through methods they are familiar with so far. The scale and potential of the social commerce industry are also the basis for the belief of e-commerce businesses to invest significant value and develop their businesses further on this platform.

Social Media Instagram is a social networking application that can be accessed via a smartphone, personal computer, or tablet connected to the internet, but Instagram is more specifically for running on mobile platforms (mobile devices) because users can capture and share photos and videos directly with their followers ( Instagram.com, 2015). Instagram is a tool in business, because in addition to being a medium for selling products, Instagram can also be a means of building relationships with consumers and become an effective medium in advertising, because now video content in the form of teasers or advertising products can also be done on Instagram with live streaming. With the increasing attractiveness of Instagram and the contents in it in an audio-visual form, Instagram has made Instagram a potential media in blasting-gathering information about a product.

The development of Instagram which is a means of promoting products such as gadgets, fashion and culinary is an example of products that use Instagram as a promotional medium. Results of Press Release No. 53 / HM / KOMINFO / 02/2018 explained the composition of internet users based on gender, consisting of 48.57 percent women, and 51.43 percent men. For the composition based on age, the largest number is in people aged 19 34 , which is 49.52 percent. However, the biggest penetration was at the age of 13-18, which was 75.50 percent. Together with the CEO and Founder of Shopie Paris, said that currently of all online sales transactions in Indonesia, around 55 percent are fashion items. Apart from bags, the fashion products that you are looking for in online stores are clothes, shoes and accessories (Lusia Kus Anna, Kompas.com 2018). It was also proven by Chris Feng as the CEO of Online Shopping Shopee that daily transactions reached 400 thousand transactions, for the highest fashion category that was in demand in Indonesia (Tito Bosnia, cnbc Indonesia.com, 2018). This makes SMEs to well-known brands use Instagram as a tool in marketing campaigns for the fashion product category. The characteristics of the Instagram platform are different from Shopee, Lazada, Tokopedia, Blibli, and Mataharimall whose development goals are clearly intended for online shopping. This is what makes this research unique, because in addition to being a means of promotional media, there are also conversations for buying and selling transactions. This proves that sometimes the market, competition, consumers, and behavior can change beyond predictions, which obliges marketers to be observant in seizing opportunities.

Business people take advantage of Instagram to advertise their products because Instagram is aapplication popular, most smartphone users use Instagram to find information about a product, they will be able to choose the right target consumers and also WOM is easier to happen through comments from fellow Instagram users which matter This can have a positive or negative impact on the flow of information that consumers get when searching for information on Instagram (Nurwibowo and Indriani, 2017).

There are also some drawbacks to shopping online via Instagram. These deficiencies, such as the number of users who 
market products on Instagram, make consumers find it difficult to determine credible marketers who can be trusted and there are often differences in expectations of what want to buy consumers with items seen in marketers' catalogs on Instagram accounts. This makes consumers have a response in the interest to buy marketed goods. According to the theory of Schiffman and Kanuk (2010: 473) purchase interest is a behavior that appears or is felt by consumers in response to objects that indicate a consumer's desire to make a purchase. Buying interest on Instagram can also be caused by consumer perceptions and trust in goods promoted by marketers. Consumer perceptions have a significant effect on buying interest online, if buyers have the perception that shopping online gets more benefits with ease of use, then buyers will prefer to shop online (Sri Rahayu, 2015) and vice versa so that buyers have the potential to choose to shop again in the conventional way. This proves that there are still doubts in consumers when they see the items to be purchased online in deciding the purchase interest on Instagram. These various shortcomings then make consumers hesitate, afraid or think repeatedly about shopping through Instagram.

The consideration in this case can be said to be one of the perceptions of risk (Perceive Risk) which tends to be negative towards goods marketed through Instagram. Social media Instagram is not one of the thirdparty applications that help consumers to claim or complain about goods that have been purchased, so there are various doubts that result in perceptions of risk that arise by consumers. According to Schiffman \& Kanuk (2010: 222) that consumer attitudes have a tendency to learn to behave in a way that is consistent or not about an object. This means that consumers who like or have a positive attitude towards a product will always have a strong desire to buy the product. Vice versa. If consumers do not like or have a negative attitude towards a product, they will not have the desire to buy that product. In consumer perception, it is influenced by the different lifestyle of each individual. The lifestyle of consumers (Consumer Lifestyle) is very different from other consumers in meeting their daily needs. Time spent by consumers shopping online through social media tends to be more desirable, which makes consumers feel time efficient than shopping at traditional stores. According to Kotler (2009: 304), lifestyle is defined as a person's lifestyle in the world which is expressed in activities, interests, and opinions so that it describes the whole person who interacts with his environment. The lifestyle of consumers has a significant effect on the interest in purchasing online shopping (Wike, 2015). It is imperative for a business person to understand and know the lifestyle that is developing in society if they want to position their products appropriately according to the lifestyle needs of consumers. Thus, the marketing target is achieved (M. Perkasa, Marketers.com, 2017). This proves that the way everyone lives to appear more attractive will make consumers affected by the items sold on Instagram and how as a marketer can give confidence for consumers to buy the products being sold. Another thing to attract consumer buying interest is a sense of consumer confidence in marketers who sell their products on Instagram. Consumers are berhati-hati in choosing the products they are looking for as well as the existing online store account on instagram social media. Where a sense of trust arises not just like that but you have to compare ratings with other stores or understand the history of the store. So trust (Trust) needs to be built with the existence of effective communication media between sellers or marketers and buyers. Trust is needed to stimulate customers to have a buying interest, so it is mandatory to build a trust in online shopping which is popularly called an electronic-trust or E-trust. Trust can be built through active marketing communications, where customers are exposed to marketing communications through the communication media they follow. This is possible through Instagram media because there is two-way communication between marketers and customers and allows quick response so that customers feel closer to the product or company. It is important for online retailers to build Trust, which can be done by increasing awareness and familiarity with cyber security measures and safe payment services for online shopping. 
Based on the background explanation above, shopping for fashion products through Instagram is not as easy as imagined. Every consumer who brings a different lifestyle when shopping directly, consumers can definitely judge the good and bad of marketers and the quality of the product directly. Compared to shopping online on Instagram, consumers only see products from photos or vendor catalogs without knowing the quality of the product directly (SWA, 2016). This is where consideration, doubt and risk taking are determined. Therefore this research focuses on the influence of Perceived Risk, Consumer Lifestyle and Online Trust which influence the interest in purchasing fashion products on social media Instagram in Surabaya.

\section{LITERATURE REVIEW Purchase Intention}

Purchase Intention is obtained from a learning process and a thought process that forms a perception. This buying interest creates a motivation that continues to be recorded in his mind and becomes a very strong desire that in the end when a consumer has to fulfill his need, he will actualize what is on his mind. Consumers anywhere and anytime will be faced with a purchase decision to make a purchase transaction. Where consumers will compare or consider one item with other goods for their consumption.

Purchase interest is a desire that arises in consumers for a product as a result of a process of observing and learning the consumer or individual about a product. Kotler and Keller (2012) in Priansa (2016: 164), reveal that buying interest is consumer behavior or the desire to own a product. Schiffman and Kanuk (2010) in Priansa (2016: 164) purchase interest will arise if a consumer is already affected by the quality and quality of a product, information about certain service products or brands, for example, such as prices, how to buy and the weaknesses and advantages of the product compared to other brands.

Pinem et al., (2019), states that one's purchase intention can be influenced by factors such as corporate image, environmental concern, price, and social influence. Meanwhile, Swastha and Irawan
(2005) in Priansa (2016: 168) the factors that influence purchase interest are related to emotional feelings, if consumers feel happy and satisfied in buying an item or service then it will strengthen purchase interest, and vice versa if the failure is happens it will lose interest. No purchase takes place if the consumer is never aware of his needs and wants. Problem recognition can occur when consumers see a significant difference between what they have and what is needed. Based on their use of the next problem, consumers seek or collect as much information as possible about the product information needed. There are two sources of information that use consumers when assessing a physical need, namely perceptions individual of physical appearance and external information sources such as other consumers. Furthermore, the information that has been obtained is combined with information that has been owned previously. All input in the form of information takes consumers to a stage where to evaluate each choice and get the best satisfactory decision from the perspective consumer's personal. The last stage there is a stage where consumers decide to buy or not buy a product.

Purchase interest is the consumer's selfinstruction to make a purchase for a product, plan, take relevant actions such as proposing, recommending, choosing, and finally making a decision to do purchase. The indicators of buying interest According to Schiffman and Kanuk (2008: 470-473), the indicators of a consumer's purchase interest are as follows:

1. Interest in seeking more information about the product.

2. Consider buying

3. Desire to know products

4. interest in trying products

5. Desire to own products

In this case Instagram social media provides everything that can stimulate consumers related to buying interest, because marketers can provide information about products that are they offer, put product displays and make settings so that they are visually appealing, display previous customer testimonials so that there is a trust that can make consumers feel confident and encourage buying interest. Purchasing interest is a very precise prediction before an actual purchase 
occurs, therefore it is important for marketers to know how the right marketing strategies and marketing media can be chosen to stimulate buying interest.

\section{Perceive Risk}

Consumers must continuously make decisions about what products and services to buy and where to buy them. Because the results or consequences of these decisions are often uncertain, consumers feel a certain level of risk in making purchasing decisions.

Schiffman \& Kanuk (2008: 170) Perceived risk is defined as the uncertainty faced by consumers if they cannot predict the consequences of their purchasing decisions. This definition highlights two dimensions of perceived risk that are relevant namely uncertainty and consequences.

In decision theory, risk and uncertainty are differentiated based on knowledge of probability in Schiffman \& Kanuk (2008: 170). Risk is defined as a situation in which the decision maker has a priori knowledge of adverse consequences and their likelihood of occurring. In addition, uncertainty is defined as a situation in which the decision-maker knows that the possible outcomes for each alternative can be identified, but there is no knowledge of the probability inherent in each.

Consumer perceptions in purchasing products from the internet are closely related to experience. Priansa (2016: 153) consumers' perceptions are different from the perceptions of other consumers even in the same situation. Schiffman and Kanuk (2008: 171) consumers' perceptions of the various perceived risks depend on the person, product, situation, and culture. The amount of risk perceived by consumers depends on the individual consumer. The level of risk perceived by consumers is also influenced by the shopping situation and the customs or culture in the environment at hand.

According to Schiffman \& Kanuk (2008) the types of risk mainthat consumers feel when making decisions about products include:

1. Financial risk is the risk that the product will not be balanced with its price.

2. Product risk refers to the quality of a product, its performance, product counterfeiting and other problems related to the product.
3. Functional risk is the risk that the product does not perform as expected.

4. Physical risk is the risk to self and others that can be caused by the product.

5. Social risk is the risk that poor product choices can cause embarrassment in the social environment.

6. Psychological risk is the risk that a poor product choice can hurt the consumer's ego.

7. risk Timeis the risk that the time used to search for the product will be useless if the product does not work as expected.

Schiffman \& Kanuk (2008: 173) Perception of risk which is considered as a basic concept in consumer attitudes which explains that consumers experience uncertainty before making a purchase for the type and level of losses estimated due to purchase and use of products.

\section{Consumer Lifestyle}

Personality describes consumers more to a perspective internal, which shows the characteristics of their patterns thinking, feelings and perceptions of something. The lifestyle desired by a person influences the buying behavior that is in him, and in turn will affect or even change the individual's lifestyle. The concept of a consumer's lifestyle is slightly different from personality. Lifestyle is related to how a person lives, how to use his money and how to allocate their time.

According to Kotler (2009: 304) defines lifestyle broadly as a way of life in a world that is expressed in activities, interests and opinions. Lifestyle describes a person's whole self in interacting with their environment.

According to Priansa (2016: 185), a lifestyle or lifestyle is a description of consumer behavior related to how to live, use their money and use their time. The Lifestyle consumer'sis different from the personality consumer's. Personality is the features characteristic in present the consumer. Although the differences between lifestyle and personality are related. Personality reflects the internal characteristics of consumers, lifestyle describes the external manifestation of these characteristics, namely the behavior displayed by consumers. 
Kotler and Keller (2009: 171) reveal that there are two families in the buyer's life. First, the family of orientation, which consists of parents and siblings. From one's parents a religious, political, and economic orientation as well as a sense of personal ambition, selfrespect, and love. Even if consumers don't interact much with their parents anymore, the influence of the parents on their behavior is enormous. Second, the procreation family (family of procreation) which consists of a spouse and children. Pre-reaction families are those that have a more direct influence on buying behavior every day. Kotler and Keller (2009: 173) say that employment factors also influence consumption patterns. The choice of products and services is very much influenced by economic and employment conditions. In this case, the company must select a market group based on occupation as its target market.

Priansa (2016: 189) Psychography is the science of measuring and grouping lifestyle patterns consumer. analysis is Psychographicalso defined as a consumer research that describes consumer segments in life, work and activities other. Psychographics are often defined as patterns of a person's life to measure the dimensions of activity, interest and opinion (AIO). The activity dimension is seen from work, hobbies, shopping, sports, and social activities. While the dimension of interest (interest) consists of food, models, family, recreation. The opinion dimension consists of themselves, social issues, business and products. Schiffman and Kanuk (2010: 48) state that psychographics are referred to as lifestyle analysis or AIO research is a form of consumer research that provides a clear and practical profile of consumer segments, important aspects of consumer personality, purchase motives, interests, beliefs, and values held by consumers. In detail, it is described as follows:

\section{Activities}

Related to statements of what consumers do, what products are purchased or used, what activities are carried out to fill spare time, and various other activities. Activity can usually be observed, but rarely measured.

2. Interests (Interest)

Interests relate to likes, hobbies and priorities in the lifestyle of consumers.
Interest is also related to objects certain, events or topics of special or constant concern to consumers.

3. Opinions (Opinions)

Opinions are the views and feelings of consumers in responding to certain issues. Opinions are used to describe interpretations, expectations, and evaluations such as beliefs about the intentions of others, anticipation regarding future events and weighing consequences that reward or punish the course of alternative actions.

\section{Online Trust}

In the context of online shopping, a person will only be able to see goods from a visual point of view (photos or videos) and sometimes accompanied by explanations or narrative information about the product, besides that the identity of the seller is also important because often traders and buyers don't meet face directly. Trust is closely related to the perceived risk of purchasing, the more a person has high trust, the lower the risk perception is found and the higher one's attitude in attitude and behavior in online purchases (Nurwibowo and Indriani, 2017), so that trust is an important determinant, especially in decisions.online purchase

Rotter'sin Priansa (2016: 115) states that trust is an expectation held by a consumer or a group when words, promises, statements in oral form or written from an individual or other group can be realized. Rotter test of trust in general to the individual against another to determine the characteristics of a person's belief using two approaches, namely demography (a position in the family,status, socioeconomic religion,etc.) and sosiometrik (dependent on the other properties of gullible, humor, and popularity)

Trust is clearly very useful and important for building relationships with consumers. Although being a trusted party is not easy and requires a concerted and brief effort. According to Mukherjee and Nath in Priansa, (2016: 124), trust can be measured through:

1. Technology Orientation

The level of individual consumer confidence in a company and the products or services sold is related to the amount of 
their trust in the system used by the company. When consumers estimate the trust factor, several problems arise in the minds of consumers and one of these problems is the compatibility of the capabilities of the system with consumer expectations. Consumers use several measures such as speed, accuracy, problem solving ability and resistance to certain situations

2. Reputation

Reputation can be defined as the overall quality or character that can be seen or assessed in general by the public. When consumers intend to make transactions with a particular company, they will consider the reputation of the company, where when consumers feel a company has a bad reputation, there is less interest in using the company's services / products.

\section{Perceived Risk}

The amount of consumer perception about risk affects the amount of their trust in a company so that when they want to use the product or service offered, consumers often assume that there is a high risk. Experienced consumers will certainly have more information about the company and the products or services that the company offering them are selling, so they think the risk is lower and therefore they have a higher trust in the company.

Shamdasani and Balakrishnan in Priansa (2016: 121) use integrity and reliability as indicators to measure customer trust and they find that contact personnel and physical environment affect customer trust.

\section{Integrity}

Integrity comes from the Latin "integrate" which means complete. Another word for complete is flawless, perfect, without a guise. In this study, complete means that there is an agreement between what the company says and does that makes consumers believe.

2. Reliability

Reliability or reliability is the consistency of a series of measurements.

In this study, reliability is intended to measure the consistency of the company in conducting its business from the past until now.

3. Contact personnel
Contact person (people who connect the company with consumers) Contact personnel are assessed based on the effectiveness of individuals in delivering services, in this case such as receptionists, telephone operators, secretaries and others.

4. Physical environment

According to Kotler (2009) Physical environment is defined as "the external surrounding and conditions in which something exists." Or it can be interpreted as a situation around and the conditions in which a person is located.

\section{Hypothesis}

Based on the theoretical basis and framework of thought previously explained, the hypotheses in this study are:

$\mathrm{H} 1$ :Perceive risk affects the purchase intention of fashion category products on Instagram.

$\mathrm{H} 2$ : Consumer Lifestyle affects the purchase intention of fashion category products on Instagram.

H3: Online Trust affects the purchase intention of fashion category products on Instagram.

\section{METHODE}

The approach used in this research is a quantitative approach. The quantitative research method is one type of research whose specifications are systematic, well-planned and clearly structured from the start to the making of the research design. According to Sugiyono (2016: 17) this research focuses on testing hypotheses by using measurable primary data and using statistical analysis methods so that it can produce generalizable conclusions.

This form of research uses descriptive methods in order to describe the object of research or research results. Understanding descriptive theory goes Sugiyono (2016: 59) is a method used to describe or give a picture of the object under study through data or samples that have been collected as is, without analyzing and making conclusions that are generally applicable. The location of this research was conducted in the city of Surabaya.

The population in this study were all Instagram users in the city of Surabaya, Indonesia. The use of samples according to 
Sugiyono (2016: 81) is part of the number and characteristics of the population. If the population is large, and the research is not possible to learn everything that is in the population, for example limited funds, energy and time, the research can use samples taken from that population. The population in this study is unknown. According to Ferdinand in Arianto (2013: 299), which reveals that in multivariate research (including those using multivariate regression analysis) the sample size is determined 25 times the Independent Variable. This study uses 3 independent variables, namely Perceive Risk, Consumer Lifestyle and Online Trust so that based on these provisions, the sample size used is $3 \mathrm{X}$ $25=75$ respondents.

In this study, the sampling technique used a non-probability sampling method. Nonprobability sampling is a sampling technique that does not provide equal opportunities or opportunities for each element or member of the population to be selected as sample members (Sugiyono, 2016: 84). The technique used is accidental sampling. The accidental sampling technique is a sampling technique based on spontaneity factors, meaning that anyone who accidentally meets the researcher and is in accordance with the characteristics (characteristics) can be used as a sample (Sugiyono, 2016: 85). The sample characteristics in this study were Instagram users who participated in the fashion category store account or had purchased the product. The accidental sampling technique in this study was used both for the sample of respondents in the questionnaire and for the sample of interview informants.

In this study, the type of data used by researchers is Primary Data, namely questionnaires as research instruments, in order to produce quantitative data, Likert scale as a measurement scale. The data analysis techniques used in this study are the validity test, reliability test, classic assumption test, multiple linear regression equations, coefficient of determination and $t$ test

\section{RESULTS AND DISCUSSION}

The significance value of the variable Perceive Risk (X1) $t$ is $0.000<0.05$, so that $\mathrm{H} 0$ is rejected and $\mathrm{H} 1$ is accepted. This shows that Perceive Risk (X1) has a negative and significant effect on Buying Interest (Y). The significance value of the Consumer Lifestyle variable (X2) $\mathrm{t}$ is $0.017<0.05$, so that $\mathrm{H} 0$ is rejected and $\mathrm{H} 2$ is accepted. This shows that Consumer Lifestyle (X2) has a positive and significant effect on Buying Interest (Y). 3. The significance value of the Online Trust variable $(\mathrm{X} 3) \mathrm{t}$ is $0.000<0.05$, so that $\mathrm{H} 0$ is rejected and $\mathrm{H} 2$ is accepted. This shows that Online Trust (X3) has a positive and significant effect on Buying Interest $(\mathrm{Y})$.

Based on the results of hypothesis testing that has been done, the results of this discussion about the influence perceive risk, consumer lifestyle and online trust towards buying interest fashion products on social media instagram in Surabaya can be presented as follows:

1. Effect perceive risk on buying interest

based on the results of research variables perceive Risk (X1) of 0.000 , less than 0.05 , which means that it is proven to have a significant effect on buying interest $(\mathrm{Y})$. The results of this study are supported by the opinion of Schiffman \& Kanuk (2008: 170) that perceived risk is defined as the uncertainty faced by consumers if they cannot predict the consequences of their purchasing decisions. This definition highlights two dimensions of perceived risk that are relevant namely uncertainty and consequences. And supported by previous research, namely Rifqi Wildan Nurwibowo and Farida Indriani (2017) concluded that the perceived risk variable has a significant negative effect on consumer buying interest in shopping for fashion through the Instagram social network. The SPSS output in the regression shows the Perceive Risk (X1) variable of -0.343 and is negative. These results can be concluded that the decreasing perceived risk to consumers, will increase the interest in purchasing fashion products on Instagram in Surabaya because consumers consider the perception of prices that are balanced with the products offered, the perceived risk that occurs in product quality and consumer comfort with the services provided. 
2. The influence of consumer lifestyle on purchase intention.

Based on the research results, the Consumer Lifestyle variable (X2) is 0.017 less than 0.05 , which means it is proven to have a significant effect on purchase intention (Y). The results of this study are supported by the opinion of Kotler (2009: $304)$ that defines lifestyle broadly as a way of life in a world that is expressed in activities, interests and opinions according to personality. Lifestyle describes a person's whole self in interacting with their environment. And supported by previous research, namely Sri Rahayu, Zuhriya, Silvia Bonita (2015) concluded that the Consumer Lifestyle variable has a significant positive effect on online purchasing decisions in Palembang. The SPSS output in the regression shows the Consumer Lifestyle variable (X2) of 0.169 and is positive. These results can be concluded that the increasing consumer lifestyle in consumers, it will increase the interest in purchasing fashion products on Instagram in Surabaya because the lifestyle of consumers tends to like to explore Instagram accounts to see the products that are sought and in demand and the lifestyle of consumers who tend to give opinions / opinions through comments on the products offered.

3. Online Effect of trust towards interest buying

Based on the results of variables Online Trust (X3) 0,000 less than 0.05 means proven to significantly influence buying interest (Y). The results of this study are supported by Rotter's opinion in Priansa (2016: 115) which states that trust is an expectation held by a consumer or a group when words, promises, statements in oral form or written from an individual or other group can be realized. And supported by previous research, namely Hadinata and Sukaris (2018) concluded that the Online Trust variable has a significant positive effect on the latest products on Instagram that users follow on purchase intentions. The SPSS output in the regression shows the Online Trust (X3) variable of 0.493 and is positive. These results can be concluded that the increasing online trust in consumers will increase the interest in purchasing fashion products on Instagram in Surabaya because consumers believe in Instagram accounts that sell their products according to the description and are consistent in their business and approaches to consumers such as service via telephone that can be contacted..or can interact with the seller.

\section{CONCLUSION}

1. There is a significant negative effect of the perceived risk variable on the interest in buying fashion products on Instagram in Surabaya.

2. There is a significant positive influence of the consumer lifestyle variable on the interest in buying fashion products on Instagram in Surabaya.

3. There is a significant positive effect of the online trust variable on the interest in buying fashion products on Instagram in Surabaya.

Based on the results of the analysis, discussion and conclusions of the research that has been carried out, the recommendations that can be given are as follows:

a. For Product Sellers on Instagram

Risk Perception: fashion product sellers on Instagram are expected to improve quality, compare with other competitors and adjust prices with descriptions of the real conditions above. products sold, this causes the perception of risk to consumers to decrease, thereby increasing consumer buying interest. Because this research proves that the decrease in Perceived Risk to consumers, it will increase the interest in purchasing products.

Consumer Lifestyle: sellers of fashion products on Instagram are also expected to be able to update their fashion products or update their latest photos on their Instagram accounts, considering that consumers prefer to explore attractive store accounts and suit the lifestyle of these consumers. Because this research proves that the increasing consumer lifestyle in consumers will increase the interest in purchasing products. 
Online Trust: from the aspect of trust, sellers of fashion products on Instagram are expected to have a responsive spirit to consumers and be willing to actively accept messages sent and maintain consistency in their business. This will make consumers trust the seller more. Because this study proves that the increasing Online Trust in consumers will increase the interest in purchasing products

b. For further researchers.

The results of this study can be used as a reference by increasing the number of samples and their variables and using different analysis techniques so that the research results are closer to reality. The real

\section{REFERENCES}

Agus Tri Haryanto. Ini Jumlah Pengguna Facebook dan Instagram di Indonesia. Available online at: https://inet.detik.com/cyberlife/d3599839/ini-jumlahpenggunafacebook-dan-instagram-diindonesia. Diakses tanggal 15 Mei 2018.

Anna, Lusia Kus. Produk Fashion Tanpa Ukuran paling laris di toko online. Available online at: https://kilasdaerah.kompas.com/jawa -tengah/read/ 2018/02/20 /153826820/produk-fashion-tanpaukuran-paling-laris-di-tokoonline. diakses tanggal 21 Oktober 2018.

APJII (2018). Jumlah pengguna internet meningkat, kominfo terus lakukan percepatan pembangunan broadband. Siaran Pers Nomor 53/HM/KOMINFO/02/2018.

Available online at: www.kominfo.go.id diakses tanggal 21 Oktober 2018.

Apriliyana, Jane. Mengintip peluang usaha dari bisnis jastip. Available online at: https://ekonomi.kompas.com/read/20 18/04/09/093700026/mengintippelua ng -usaha -dari-bisnis-jastip. diakses tanggal 17 Oktober 2018.
Bosnia, Tito. Produk Fashion paling diminati dalam Belanja Online. Available online at: https://www.cnbcindonesia.com/lifes tyle/20180119164658-332018/produk-fashion-palingdiminati-dalam-belanja-online. Diakses tanggal 21 Oktober 2018

Ghozali, Imam (2018). Aplikasi Analisis Multlivariate dengan Program IBM SPSS. Penerbit Universitas Diponegoro, Yogyakarta.

Hafiz, M Perkasa Al. lifestyle Marketing Perkuat Ikatan Emosional. Available Online at http://marketeers.com/lifestylemarketing-guide-memperkuatikatanemosional/. diakses tanggal 21 oktober 2018.

Hartini, S., Mardhiyah, D. and Sukaris (2020) 'A conceptual framework for relationship between symbolic risk consumption with electronic word of mouth', Opcion, 36(Special Edition 26), pp. 1282-1295.

Kotler keller. Marketing Management (2009) . Jilid I. Edisi ke 13. Erlangga, Jakarta.

Laudon. Kenneth C dan Laudon. Jane P (2015). Sistem informasi Manajemen : Mengelola perusahaan digital. Edisi 13. Penerbit salemba Empat, Jakarta.

Lubis, Mila. Pengguna Smartphone meningkat, Belanja Iklan Produk seluler meroket. Available online at: https://www.nielsen.com/id/en/press room/ 2018/pengguna-smartphonemeningkat-belanjaiklan-produkselularmeroket. html. Diakses tanggal 21 Oktober 2018

Nata. Jiwangga Hadi, Sukaris. Pengaruh Aktifitas Browsing, Flow, dan Kepercayaan Online terhadap Niat pembelian Barang-Barang Baru di Instagram. Jurnal Inovasi Bisnis dan Manajemen Indonesia Vol. 2, Nomor. 1 Desember 2018.

Nurwibowo. Rifqi Wildan, Indriani Farida. Analisis Faktor - Faktor yang 
Mempengaruhi Minat Beli Konsumen Terhadap Produk Fashion Online Melalui Jerjaring Sosial Instagram. Diponegoro Journal Of Management Volume 6, Nomor 2, Tahun 2017, Halaman 1-9.

Olyvia, Filani. Alasan Orang Indonesia lebih senang belanja via media sosial. Available online at: https://www.cnnindonesia.com/gayahidup/2017092 0195716-282243056/alasan-orang-indonesialebih-senang-belanja-viamediasosial . diakses tanggal 17 Oktober 2018.

Perdana, Jaka. Jumlah pengiklanan di Instagram tembus satu juta setiap bulan. Available online at: http://marketeers.com/pengiklaninstagram-tembussatu-juta/ . diakses tanggal 17 Oktober 2018

Pinem, Robetmi \& Purbawati, Dinalestari \& Srifitriani, Abditama \& Wahyoedi, Soegeng \& Sukaris,. (2019). Green Companies and the Millennial Generation as the Spearhead of the Environment. International Journal of Innovation, Creativity and Change. 8. 106-115.

Priansa, Donni Juni (2017). Perilaku Konsumen Dalam Persaingan Bisnis Kontemporer. Penerbit Alfabeta, Jakarta.

Rahayu. Sri, Zuhriya, Bonita Silvia. Pengaruh Gaya Hidup dan Persepsi Mahasiswa Terhadap Keputusan Pembelian Secara Online di Kota Palembang. Jurnal Manajemen dan Bisnis Sriwijaya Vol 13 No. 3 September 2015

Saidani, Basrah dan Samsul Arifin, 2012. Pengaruh Kualitas Produk dan Kualitas layanan terhadap kepuasan konsumen dan minat beli pada ranch market. Jurnal Riset Manajemen Sains Indonesia (JRMSI), Vol 3 No. 1,2012
Schiffman, L.G dan Kanuk, Lesley L. 2008. Perilaku konsumen. Edisi 7. Pearson, Jakarta

Schiffman, L.G dan Kanuk, Lesley L. 2008. Perilaku konsumen. Edisi1 10. Pearson, Jakarta

Sugiyono, 2016. Metodologi Penelitian Kuantitatif, Kualitatif dan R\&D. Alfabeta, Bandung

Sukaris, S., Hartini, S. and Mardhiyah, D. (2019) 'Increasing Electronic Wordof-Mouth Activities through SelfCongruity and Tourist Values', International Journal of Innovation, Creativity and Change, 9(10), pp. 162-183.

Swaonline. Memahami Perilaku belanja online. Availble online at: https://swa.co.id/swa/myarticle/memahami-perilaku-belanjaonline . diakses tanggal 21 oktober 2018. 